\title{
THE EFFECT OF VIRTUAL MEDIA-BASED OBSTACLE RUN TRAINING ON WOMAN FUTSAL PLAYER'S DRIBBLING ABILITY DURING COVID-19 PANDEMIC
}

\author{
Muhammad Syamsul Taufik ${ }^{1 \mathrm{AC}}$, Soleh Solahuddin ${ }^{2 \mathrm{CDE}}$, \\ Reza Resah Pratama ${ }^{3 \mathrm{AB}}$, Tatang Iskandar ${ }^{4 \mathrm{CD}}$, Azi Faiz Ridlo ${ }^{5 \mathrm{CB}}$ \\ ${ }^{1}$ University of Suryakancana \\ ${ }^{2,3}$ University of Sriwijaya \\ 4, 5 Islamic University 45 of Bekasi \\ Authors' Contribution: A - Study design; B - Data collection; C - Statistical analysis; D - Manuscript Preparation; E - Funds Collection
}

Corresponding Author: Muhammad Syamsul Taufik, E-mail: syamsul@unsur.ac.id

Accepted for Publication: October 16, 2021

Published: December 25, 2021

DOI: 10.17309/tmfv.2021.4.02

\begin{abstract}
The study purpose. This study aimed to observe the effect of virtual media-based obstacle run training on dribbling ability of women futsal players in the Women's Futsal Student Activity Unit (UKM) during the Covid-19 pandemic by examining the effect of the treatment.

Materials and methods. The research used a pre-experiment method using a quantitative descriptive approach with One Group Pretest-Posttest Design. A total of 30 students who participated in the Women's Futsal UKM at the University of Suryakancana became the research population. These female futsal athletes are campus team amateur athletes below the professional level of the Indonesian Futsal League.

Results. Based on research data, the average value before the obstacle run training treatment was 10.840 seconds and after the treatment was 9.600 seconds, which means that there was time reduction, or in other words, the woman futsal player's dribbling ability increased. The result of the test showed that the value of the interval training results before and after being given was 0.859 .

Conclusions. It is suggested that further research explore the use of different kinds of media in improving the dribbling skills of futsal athletes during the Covid-19 pandemic.

Keywords: futsal, dribbling, Covid-19, virtual zoom.
\end{abstract}

\section{Introduction}

Ranging from children to adults in the world, considering that the game is easy to learn and not difficult to play (Nogueira et al., 2018) In the Futsal game, there are several basic techniques that must be mastered by a Futsal player. Futsal is a variant of association football that is played on a smaller pitch and mainly played indoors (Varkiani et al., 2013). The basic techniques include passing, holding the ball (control), chipping, dribbling, shooting, and heading (Pelana et al., 2020). A Futsal player must have good individual techniques and excellent physical condition to build cooperation between teammates and produce victory (Barcelos et al., 2017). Therefore, the ability of dribbling is important to be mastered by current futsal players in order to pursue

(c) Syamsul Taufik, M., Solahuddin, S., Pratama, R. R., Iskandar, T., \& Ridlo, A. F., 2021. maximum achievements because Futsal players with good dribbling skills are able to create effective games that can produce victories. Each player certainly has different kick performance abilities, this can be seen from several factors from the physical component and the quality of training (Matzenbacher et al., 2014).

Futsal competitions between universities in Indonesia are rapidly growing and being held more and more every year, especially in the West Java region. Not only for men, but also for women, where Suryakancana University was once the Runner Up at Futsal Pakuan Women's Cup 2019. This achievement is a matter of pride for the Futsal Student Activity Unit (UKM) of Suryakancana University and becomes a benchmark for achieving better achievements. But at the end of 2019 and early 2020, there were obstacles and a global epidemic that befell people around the world which of course includes Indonesia. The outbreak, called 
the Covid-19 epidemic, initially appeared in Wuhan, China, which caused problems and obstacles for the community in carrying out physical activities and sports. In sports competitions, athletes usually break previous records and set new ones (Rezaimanesh et al., 2011).

Regarding the outbreak and the emergence of the Covid-19 epidemic, the process of regaining achievements, such as the runner up at Pakuan Women's Cup 2019, and carrying out the planned training schedule has been disrupted so that athletes find it difficult to do activities and trainings, especially the training programs that has been planned by coach. Training is a process that must be done by every athlete if he wants to increase his abilities (T. Bompa \& Carrera, 2015), so the process of improvement requires what is called training, because an athlete who is diligent in implementing the right training program will get the best results in his performance (T. O. Bompa \& Buzzichelli, 2019). Training is a necessity for every athlete, thus, in training, it needs to be supported by a good training program (Pate et al., 2016) It is explained that mental formation training is specifically aimed at forming sportsmen who not only have physical, technical, and tactical abilities, but also have the maturity and high mental qualities to win the matches (Kirkham-King et al., 2017) The opinions of several experts above show the importance of training to increase achievement, but in this pandemic it is very difficult to carry out the training so that a form of training that can be used in this pandemic is needed. One form of training that can be used is training with virtual media. By using the online room, the exercise can be carried out via a video call or a zoom room application. In this method, the learning / training media that generally can be used are VCD (video compact disk) or DVD (video disk drive) (Osgerby, 2013) Exercise is usually defined as a systematic process that is carried out in the long term, repetitive, progressive, and has the aim of improving physical appearance (van der Graaf et al., 2020). Many factors affect the performance of students or athletes, these factors are physical, technical, tactical or strategic, and mental abilities (Bramantoro et al., 2020) From some of the opinions above, it can be concluded that obstacle run training for a Futsal athlete using virtual media is needed to improve the players' movement ability in order to master the dribbling technique.

The observations on dribbling skills of female students who take part in the Futsal UKM, Suryakancana University, were the background of the author's interest in conducting this research. During the observation, the writer saw that there were still many students who made basic mistakes when doing dribbling. They still often did long dribbling to easily take the ball by the opponent (González-Ródenas et al., 2019). To improve dribbling skills, programmed and appropriate training is needed to achieve the expected results. Obstacle Run was used in this study to improve dribbling skills of female students involved in Futsal UKM, Suryakancana University. Obstacle Run training is a form of training that supports improving dribbling skills with virtual media use due to constraints of Covid-19.

\section{Materials and Methods}

\section{Study participants}

A total of 30 students who participated in the Women's Futsal UKM at University of Suryakancana became the research population. These female futsal athletes are campus team amateur athletes below the professional level of the Indonesian Futsal League. The sampling technique was Random Sample Test. The research was conducted from April to May 2020 at University of Suryakancana sports field.

\section{Study organization}

This research conducted a pre-experiment using a quantitative descriptive approach with the One Group PretestPosttest research design. Presenting the facts of the problematic symptoms systematically will make the analysis easier to understand and conclude (Tangkudung, 2018). The researcher first conducted a pretest on the group receiving treatment. Then, researchers did the treatment. When the treatment was finished, the researcher conducted a post-test. The magnitude of the effect of treatment can be known accurately by comparing the results of the pre-test and post-test.

The study was conducted for 16 meetings with training frequency 3 times a week.

In this study, a pre-experiment was conducted using a quantitative descriptive approach with the One Groups Pretest-Posttest research design, including (pre-test): conducting an initial test of dribbling before the sample received the treatment, X: implementing the treatment which was the obstacle run training using virtual zoom media, (post-test): performing the final test to see whether there was an improvement after the sample received the obstacle run training through virtual media or not. The instrument test used in this study was dribbling test instrument which specifically aimed to determine the Futsal player dribbling ability (Figure 1). This

Table 1. Training Procedure, 16 Zoom App Meetings

\begin{tabular}{|c|c|c|}
\hline Warm Up & Obstacle Run Coaching Points: & Training Targets for Each Meeting For 16 Meetings \\
\hline 1. Preliminary & 1. Dribbling ability & 1. First step: run and then jump and bounce the ball \\
\hline 2. Introduction & 2. Dribbling touch quality & $\begin{array}{l}\text { 2. Second step: run past the Hurdle jump and do a } \\
\text { stap run }\end{array}$ \\
\hline 3. lined up pray & $\begin{array}{l}\text { 3. Concentration - Movement } \\
\text { Adaptation }\end{array}$ & 3. Third Step: Players carry out Hurdle jumps and stap \\
\hline 4. Explanation & & 4. Fourth Step: run with the ball over the hurdle \\
\hline 5. Material & & $\begin{array}{l}\text { 5. All Exercises Are Virtually Performed With ZOOM } \\
\text { App }\end{array}$ \\
\hline 6. Warm Up & & \\
\hline
\end{tabular}




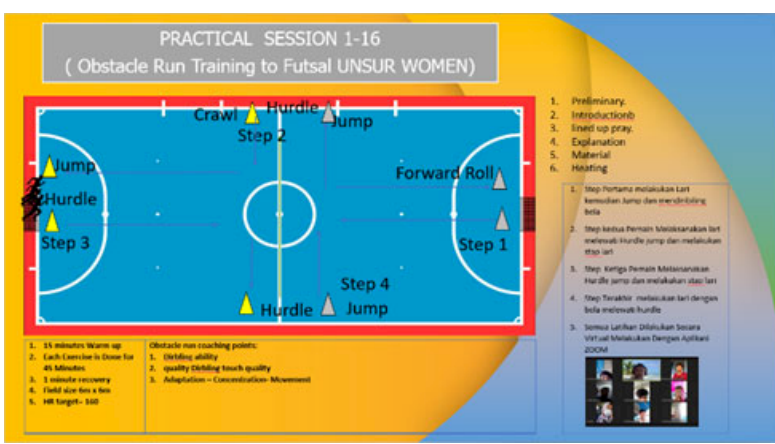

Fig. 1. Pratical 16 Meetings With 3 Times A Week Training Frequency

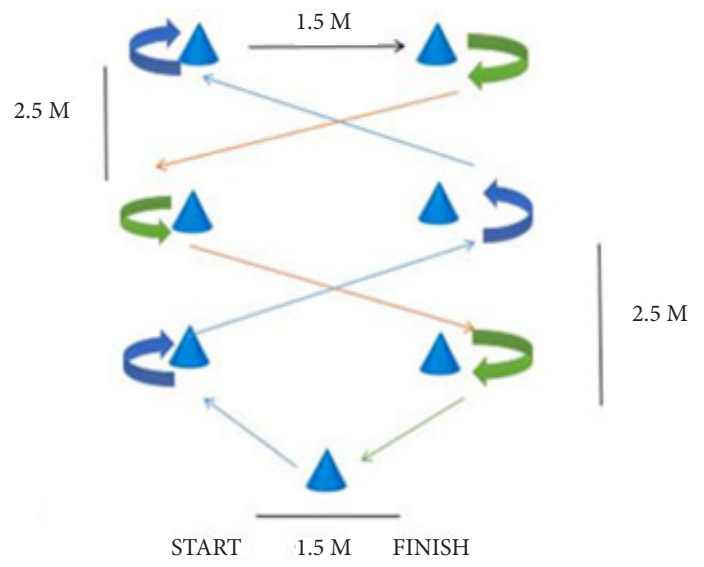

Fig. 2. Futsal Dribbling Test Instrument

Futsal dribbling test instrument, with a validity of 0.89 along with a reliability of 0.71 , can be stated feasible to be used to measure dribbling abilities.

\section{Statistical analysis}

Statistical processing of the data was carried out on a computer using the standard SPSS 25 programs.

\section{Result}

The female students' dribbling skill of Futsal UKM, University of Suryakancana, was improved after receiving treatment. The mean value results of students' dribbling test decreased after receiving treatment. This can be seen in Table 2: Mean value results of dribbling paired samples statistic.

Table 2 shows that the average dribbling ability score of students who participated in the Suryakancana University women Futsal UKM before receiving the training was 10.8400 seconds and after receiving treatment with the Virtual MediaBased Obstacle Run Training was 9,600 seconds. This means

Table 2. Mean value results of dribbling paired samples statistic

\begin{tabular}{llrrcc}
\hline & & N & Mean & Std.deviation Std.Error Mean \\
\hline \multirow{2}{*}{ Pair 1 } & Pre-Test & 30 & 10.84 & 1.475 & 0.208 \\
\cline { 2 - 6 } & Post Test & 30 & 9.46 & 1.064 & 0.150 \\
\hline
\end{tabular}

that there was a decrease in time, which indicates that there was an improvement on students' Futsal dribbling skills after carrying out the Virtual Media-Based Obstacle Run Training.

The result of the test, with the value of the interval training before and after receiving treatment, was significantly improved. The results of dribbling correlation coefficient can be seen in Table 3: Results of the dribbling correlation coefficient paired samples correlations.

Based on the results of the output in Table 3, the effect coefficient of virtual media-based Obstacle Run Training on Dribbling Ability of women Futsal UKM, University of Suryakancana, before and after receiving treatment is 0.859 with a p-value of $0.00<0.05$, which concludes that there was a significant effect.

Table 3. Results of the dribbling correlation coefficient paired samples correlations

\begin{tabular}{ccccc}
\hline & & N & Correlation & Sig. \\
\hline Pair 1 & Pre_Test \& Post_Test & 30 & 0.859 & 0.000 \\
\hline
\end{tabular}

\section{Discussions}

The main factor in dribbling ability in order to beat opponents lies in the speed of the dribbling in the match. This is reinforced by the statement of (Beltrão de Matos, 2008) that said Futsal athletes have good dribbling skills if their time records are shorter when passing through obstacles. In this discussion, it can be said that the Obstacle Run practice through virtual media in the form of zoom meetings and google meetings has a significant effect. Therefore, it can be concluded that training is a support in maximizing achievements. In the covid-19 pandemic situation, trainers have to be more innovative and initiative, one of which is by carrying out training through virtual media. Currently, virtual classes have begun to be used as an alternative for learning (Riemann et al., 2020). This is because learning is no longer bound by time and space. So, practices can be carried out virtually and obstacle run training through virtual media can be carried out well so that it can increase dribbling skills, because virtual training can be done anywhere according to situations that make it impossible to carry out regular training in the Covid-19 epidemic. Virtual Classroom uses a combination of several tools to recreate a structure and learning experience from a physical classroom (Hassenfeldt et al., 2020) Virtual Classroom is a special application of social learning (O'Connor et al., 2020). Virtual reality is an innovative technology that enables students to practice sport. This study shows specific results, an increase in dribbling ability. Increased dribbling skills can help improve performance. In obstacle training, which is carried out through virtual media, it can be done in various places. It is called a virtual class because this exercise can help the process and progress of the training during Covid-19. Sports activities involve components of physical fitness, because physical components are the basis of human movement or physical activity, in addition to exercises that can strengthen ligaments, tendons, and bones (Pérez-Turpin et al., 2019). Exercise is a process that is done repeatedly to improve the physical quality and functional ability of the body's equipment to achieve planned goals. Exercises must be planned systematically and programmed so that the goals are planned. Therefore, planning is important for trainers in their efforts to direct a well-organized training program [5]. Based 
on the opinion above, it can be seen that almost all virtual media can be used and utilized to support the process of conveying messages or materials. Virtual media can be helpful as a coach supporter element or as the main training element.

A relevant research states that there is an effect of obstacle run and down the line drill on the agility of the extracurricular football participants of Buah Batu 1 junior high school in 2015 (Suwariana et al., 2015). The most utilized rotation and translation movement while in the ball-possession among futsal players (Ismail et al., 2016). The effect of squat thrust and obstacle run exercises on increasing agility of badminton players and the effect of fartlek and obstacle run training on cardiorespiratory resistance It can be concluded that obstacle training carried out through virtual media impacts the dribbling ability of the University of Suryakancana Women Futsal UKM. Prior to the training of obstacle run based on virtual media, the dribbling ability was 10,8400 seconds. Meanwhile, after receiving virtual training, it was 9.600 seconds. This means that there was a decrease in time, so that women Futsal dribbling skills were said to have increased. The test results with an interval value of $0.00<0.05$ showed a significant effect. It shows that there is a significant effect on the ability of female students' futsal dribbling skill after receiving obstacle run training through virtual media. The most important thing about this exercise is that it can be done anywhere, especially in a pandemic situation that limits activities in public sports facilities, which cannot be done in practical trainings in general.

\section{Conclusion}

Any comments and suggestions are welcomed so that we can constantly improve this template to satisfy all authors' research needs. From the data analysis results and discussion that have been stated, it can be concluded that the virtual media-based obstacle runs training has a significant effect on increasing the dribbling ability of the women futsal UKM, University of Suryakancana.

Suggestions and recommendations for further research are to use other training models based on virtual media that can be developed and to create several options where athletes can choose the training menu independently based on their needs.

\section{Acknowledgement}

We want to express our gratitude to all authors and university institutions who have always supported all of these research activities. We want to thank the Chancellor and Dean of the FKIP University of Suryakancana and the students that supported the implementation of this research. We also would like to express our gratitude to the Universitaty of Suryakancana futsal coach and all parties that we cannot mention in this research. I hope this research can continue to analyse hitting skills from other parameters.

\section{Conflict of interest}

The authors state no conflict of interest.

\section{References}

Nogueira, F. C. d. A., de Freitas, V. H., Nogueira, R. A., Miloski, B., Werneck, F. Z., \& Bara-Filho, M. G. (2018). Mejora del rendimiento físico, perfil hormonal, balance estrés-recuperación y aumento del daño muscular basado en la planificación específica de pretemporada en el fútbol sala. Revista Andaluza de Medicina Del Deporte, 11(2), 63-68. https://doi.org/10.1016/j.ramd.2015.11.008

Varkiani, M. E., Alizadeh, M. H., \& Pourkazemi, L. (2013). The Epidemiology of Futsal Injuries Via Sport Medicine Federation Injury Surveillance System of Iran in 2010. Procedia - Social and Behavioral Sciences, 82, 946-951. https://doi.org/10.1016/j.sbspro.2013.08.001

Pelana, R., Taufik, M. S., \& Setiakarnawijaya, Y. (2020). Futsal Training Model with Futsal Measurement Tests for College Student-Athletes. Talent Development \& Excellence, 12(1), 4398-4410. http://iratde.com/index.php/jtde

Barcelos, R. P., Tocchetto, G. L., Lima, F. D., Stefanello, S. T., Rodrigues, H. F. M., Sangoi, M. B., Moresco, R. N., Royes, L. F. F., Soares, F. A. A., \& Bresciani, G. (2017). Functional and biochemical adaptations of elite level futsal players from Brazil along a training season. Medicina (Lithuania), 53(4), 285-293. https://doi.org/10.1016/j.medici.2017.08.001

Matzenbacher, F., Pasquarelli, B. N., Rabelo, F. N., \& Stanganelli, L. C. R. (2014). Physiological demands of futsal competition. Physical and physiological characteristics of professional players. Revista Andaluza de Medicina Del Deporte, 7(3), 122-131. https://doi.org/10.1016/S1888-7546(14)70074-7

Rezaimanesh, D., Amiri-Farsani, P., \& Saidian, S. (2011). The effect of a 4 week plyometric training period on lower body muscle EMG changes in futsal players. Procedia Social and Behavioral Sciences, 15, 3138-3142. https://doi.org/10.1016/j.sbspro.2011.04.260

Bompa, T., \& Carrera, M. (2015). Conditioning Young Athletes. Bompa, T. O., \& Buzzichelli, C. A. (2019). Peridization: Theory and Methodology of Training. Journal of Chemical Information and Modeling, 53(9).

Pate, R. R., Brown, W. H., Pfeiffer, K. A., Howie, E. K., Saunders, R. P., Addy, C. L., \& Dowda, M. (2016). An intervention to increase physical activity in children: A randomized controlled trial with 4-year-olds in preschools. American Journal of Preventive Medicine, 51(1), 12-22. https://doi.org/10.1016/j.amepre.2015.12.003

Kirkham-King, M., Brusseau, T. A., Hannon, J. C., Castelli, D. M., Hilton, K., \& Burns, R. D. (2017). Elementary physical education: A focus on fitness activities and smaller class sizes are associated with higher levels of physical activity. Preventive Medicine Reports, 8 (May), 135-139. https://doi.org/10.1016/j.pmedr.2017.09.007

Osgerby, J. (2013). Students' Perceptions of the Introduction of a Blended Learning Environment: An Exploratory Case Study. Accounting Education, 22(1), 85-99. https://doi.org/10.1080/09639284.2012.729341

Van der Graaf, J., Segers, E., \& de Jong, T. (2020). Fostering integration of informational texts and virtual labs during inquiry-based learning. Contemporary Educational Psychology, 62(June), 101890. https://doi.org/10.1016/j.cedpsych.2020.101890

Bramantoro, T., Hariyani, N., Setyowati, D., Purwanto, B., Zulfiana, A. A., \& Irmalia, W. R. (2020). The impact of oral health on physical fitness: A systematic review. Heliyon, 6(4). https://doi.org/10.1016/j.heliyon.2020.e03774

González-Ródenas, J., López-Bondia, I., Aranda-Malavés, R., Tudela Desantes, A., Sanz-Ramírez, E., \& Aranda Malaves, R. (2019). Technical, tactical and spatial indicators related to goal scoring in European elite soccer. Journal of Human Sport and Exercise, 15(1), 186-201. https://doi.org/10.14198/jhse.2020.151.17

Tangkudung, J. W. (2018). Sport Psychometrics. Vol. 1.

Beltrão de Matos, J. A. (2008). Acceleration capacity in futsal and soccer players. Fitness \& Performance Journal, 7(4), 224-228. https://doi.org/10.3900/fpj.7.4.224.e

Riemann, T., Kreß, A., Roth, L., Klipfel, S., Metternich, J., \& Grell, P. (2020). Agile implementation of virtual reality in 
learning factories. Procedia Manufacturing, 45(2019), 1-6. https://doi.org/10.1016/j.promfg.2020.04.029

Hassenfeldt, C., Jacques, J., \& Baggili, I. (2020). Exploring the Learning Efficacy of Digital Forensics Concepts and Bagging \& Tagging of Digital Devices in Immersive Virtual Reality. Forensic Science International: Digital Investigation, 33, 301011. https://doi.org/10.1016/j.fsidi.2020.301011

O’Connor, M., Stowe, J., Potocnik, J., Giannotti, N., Murphy, S., \& Rainford, L. (2020). 3D virtual reality simulation in radiography education: The students' experience. Radiography, 27(1), 208-214. https://doi.org/10.1016/j.radi.2020.07.017

Pérez-Turpin, J. A., Gomis-Gomis, M. J., Pérez-Suárez, P., \& Suárez-Llorca, C. (2019). Maxforce: The new option in strength, health levels and life expectancy measurement. Journal of Human Sport and Exercise, 14(4), 841-855. https://doi.org/10.14198/jhse.2019.144.13

Suwariana, I. P. A., Or, S. P. M., Kardiawan, I. K. H., \& Pd, S. (2015). The Effect of Obstacle Run And Down The Line Drill Training on Agility in Football Extracurricular Participants at SMP Negeri 1 Blahbatuh TAHUN 2015 Jurnal Pendidikan Kepelatihan Olahraga Undiksha, 8(2), 2-3. https://doi.org/10.23887/jjpko.v8i2.7761

Ismail, S. I., Sulaiman, N., \& Adnan, R. (2016). The Most Utilized Rotation and Translation Movement while in BallPossession among Futsal Players. Procedia Engineering, 147, 116-121. https://doi.org/10.1016/j.proeng.2016.06.199

\title{
ВПЛИВ ТРЕНУВАННЯ 3 БІГУ 3 ПЕРЕШКОДАМИ ЗА ДОПОМОГОЮ ВІРТУАЛЬНИХ МЕДІА НА ВМІННЯ ДРИБЛІНГУ У ФУТЗАЛІСТОК ПІД ЧАС ПАНДЕМІї COVID-19
}

\author{
Мухаммад Сямсул Тауфік ${ }^{1 \mathrm{AC}}$, Солех Солахуддін ${ }^{2 \mathrm{CDE}}$, \\ Реза Реса Пратама ${ }^{3 A B}$, Татанг Іскандар ${ }^{4 D C}$, Азі Фаїз Рідо \\ 'Університет Сур'яканчана, \\ 2,3Університет Шрівіджаї \\ 4,5 Ісламський університет 45 Бекасі
}

\begin{abstract}
Авторський вклад: А - дизайн дослідження; В - збір даних; C - статаналіз; D - підготовка рукопису; Е - збір коштів
Реферат. Стаття: 5 с., 3 табл., 2 рис., 35 джерел.
\end{abstract}

Мета дослідження - дослідити вплив тренування з бігу з перешкодами за допомогою віртуальних медіа на здатність дриблінгу у футзалісток секції жіночого футзалу відділу студентської діяльності (UKM) під час пандемії Covid-19.

Матеріали та методи. У дослідженні використовувався передекспериментальний метод з кількісним описовим підходом за планом попереднього та підсумкового тестування однієї групи. Учасниками дослідження стали 30 студенток, які займаються у секції жіночого футзалу відділу студентської діяльності (UKM) Університету Сур якканчана. Ці футзалістки є спортсменами-аматорами університетської команди з підготовкою нижче професійного рівня Індонезійської футзальної ліги.
Результати. За даними дослідження, середнє значення до тренування з бігу з перешкодами становило 10,840 секунд, а після - 9,600 секунд, тобто відбулося зменшення часу, або, іншими словами, вміння дриблінгу у футзалісток підвищилося. Результат тесту показав, що значення результатів інтервального тренування до і після проведення становило 0,859.

Висновки. Пропонується подальше дослідження використання різних видів медіа для покращення навичок дриблінгу у футзалістів під час пандемії Covid-19.

Ключові слова: футзал, дриблінг, Covid-19, віртуальний Zoom.

\section{Information about the authors:}

Syamsul Taufik Muhammad: syamsul@unsur.ac.id; http://orcid.org/0000-0001-5936-515X; Physical Education Department, University of Suryakancana, 1. Pasirgede Raya, Bojongherang, Kec. Cianjur, Kabupaten Cianjur, Jawa Barat 43216, Indonesia.

Solahuddin Soleh: solehsolahuddin@fkip.unsri.ac.id; https://orcid.org/0000-0001-8959-3073; Physical Education Department, University of Sriwijaya, Jl. Masjid Al Gazali, Bukit Lama, Kec. Ilir Bar. I, Kota Palembang, Sumatera Selatan 30128, Indonesia.

Pratama Reza Resah: rezaresah@fkip.unsri.ac.id; https://orcid.org/0000-0003-1118-8902; Physical Education Department, University of Sriwijaya, Jl. Masjid Al Gazali, Bukit Lama, Kec. Ilir Bar. I, Kota Palembang, Sumatera Selatan 30128, Indonesia.

Iskandar Tatang: tatang@unismabekasi.ac.id; https://orcid.org/0000-0003-4164-6097; Physical Education Department, Islamic University 45 of Bekasi, Jalan Cut Meutia No. 83, Bekasi, 17113 West Java, Indonesia.

Ridlo Azi Faiz: azifaizridlo@unismabekasi.ac.id; https://orcid.org/0000-0002-1686-3877; Physical Education Department, Islamic University 45 of Bekasi, Jalan Cut Meutia No. 83, Bekasi, 17113 West Java, Indonesia.

Cite this article as: Syamsul Taufik, M., Solahuddin, S., Pratama, R. R., Iskandar, T., \& Ridlo, A. F. (2021). The Effect of Virtual Media-Based Obstacle Run Training on Woman Futsal Player's Dribbling Ability During Covid-19 Pandemic. Teoriâ ta Metodika Fizičnogo Vihovannâ [Physical Education Theory and Methodology], 21(4), 299-303. https://doi.org/10.17309/tmfv.2021.4.02

Received: 12.09.2021. Accepted: 16.10.2021. Published: 25.12.2021

This work is licensed under a Creative Commons Attribution 4.0 International License (http://creativecommons.org/licenses/by/4.0). 